Murmurations:

Journal of

Transformative

Systemic

Practice

\title{
The peculiar experience of being a complete novice: a reflection on supervising systemic practitioner researchers.
}

\author{
Alfredo Gaitàn
}

\section{Volume 1}

Issue 1

Winter 2017

\author{
Keywords: \\ growth and safety, \\ doctoral supervision, \\ systemic research, \\ joint action, \\ significant learning
}

\section{Citation Link}

\begin{abstract}
The experience of being a novice sailor has put me in a peculiar, but privileged, position to gain a deeper understanding of the experience of an adult learner who is also a competent professional. I initially used first-person writing in order to express and explore my experience of a week of sailing in the Norfolk Broads. I tried to capture, among many things, my fear of falling in the water, of failing and of embarrassment. I described how I overcame my fear as I enjoyed small success at simple tasks. I then reflected on what I could learn about these experiences in nine themes, drawing on ideas by Maslow (1968/1972) on growth and safety, but also by Rogers (1951) on significant learning, and the all-important role of support and skilful guidance, with doctoral students and supervisors in mind. I drew on Shotter's (1993, 2013) notions of "joint action" and "third agency" in order to explore the student-supervisor relationship and the construction of knowledge that takes place during a doctorate. This author's ideas seemed particularly wellsuited to the description of learning and supervising, as involving a way of being in which we are mostly responding to the requirements of concrete circumstances in a fluid process. I tried to infer what the appropriate skills and pedagogical strategies needed on the part of the supervisor may be. However, it is possible that the readers discover more possibilities hidden in the metaphor of learning to sail as they apply it to their own experience of learning in the doctoral programme.
\end{abstract}

\footnotetext{
Abstract (Spanish)

La experiencia de ser un marino novato me ha puesto en una posición peculiar pero, a la vez privilegiada, que me permite obtener una comprensión profunda de la experiencia de un aprendiz adulto que es también un professional compentente. Inicialmente, usé un escrito en primera persona para expresar y explorar my experiencia de una semana navegando en velero en los Norfolk Broads. Intenté captar, entre otras cosas, mi miedo de caer al agua, de fracasar y de hacer el ridículo. Describí cómo me sobrepuse at miedo a medida que disfrutaba pequeños éxitos en tareas sencillas. Luego reflexioné sobre lo que podía aprender de esas experiencias en nueve temas, basado en ideas de Maslow (1968/1972) sobre el crecimento y la seguridad, pero también de Rogers (1951) sobre el aprendizaje significativo y el paper fundamental del apoyo y la orientación, con los alumnos de doctorado y sus supervisors en mente. Hice uso de las nociones de "accion conjunta" y "tercera agencia" de Shotter (1993, 2013). Las ideas de este autor resultaron particularmente apropiadas para describir el aprendizaje y la supervisión, en tanto que involucran una forma de ser en la que, por sobre todo, respondemos a los requerimentos de las circunstancias concretas en un proceso fluido. Intenté inferir cuáles serían las habilidades y estrategias pedagógicas necesarias para un supervisor. Sin embargo, es bien possible que el lector descubra más posibilidades ocultas en la metáfora de aprender a navegar, a medida que la aplican a su propia experiencia de aprendizaje en el programa de doctorado.
} 
The rain fell relentlessly. I wasn't cold, but I was drenched and the deck, less than a foot wide, was slippery. I was trying to walk along the deck while lifting and then pushing a 15 foot pole called a "quant" into the mud so that our boat kept moving through the dyke, as there was not enough wind. In fact, no wind at all. The four of us took turns. Another member of the crew had quanted before, so I had a chance to observe how it was done. I had read about it in the handbook, but the instructions did not seem to bear much resemblance to what was required in practice. Each time I dropped the quant and pushed, I feared it would stick in the mud and I would not be able to pull it out. But my worse fear was falling in the water. Several times I nearly lost my balance and did not have anything to hold onto, as I needed both hands to hold the heavy quant.

How did I end up in this stressful situation? Why was I experiencing so much fear? The second question is easier to answer: I was no sailor and had no experience of sailing whatsoever. The truth is I feel more comfortable on land than on water. Having grown up in the Colombian Andes, water sports had not been a part of my upbringing. I'd rather be on a horse than on a boat, anytime. So, why did I choose to go on a sailing holiday for a week in the Norfolk Broads? That is a more complex question. Well, my wife has recently learned to sail and wanted to share the experience with me, perhaps in the hope that I would end up liking it and maybe take up sailing. Yes, I wanted to make her happy, but there were other reasons too. I had been on the Broads for a weekend before, so I knew what I was letting myself in for. I was aware that it would be difficult in many ways, but being a firm believer in the value of challenges as a key factor for significant learning and growth, I saw this as my chance to practice what I preached.

I concentrated on walking, raising the quant as I walked forward, carefully choosing the place to drop it, not too far from the boat that I wouldn't be able to push effectively, but not so close that the quant could get dragged under the boat as it swayed (this nearly happened once or twice). I tried to let the wood slip through my hands quickly, so I could push as soon as possible. Sometimes, the quant went in very deep and I had to pull it out, as there was no point in pushing. Other times, the depth was right and I could give it a good long push. After a while, I got the hang of it and a feeling of satisfaction gradually replaced the fear, to the extent that I insisted on carrying on after my 5-minute turn was over. The others praised me and it was good to feel useful, in particular because before I had thought I would be more of a hindrance than a help to the crew.

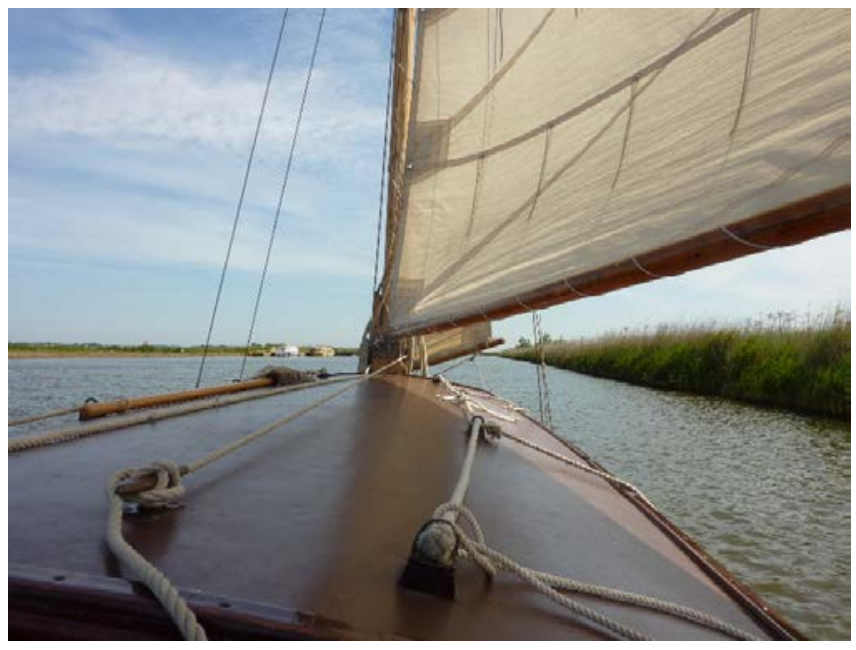

I was glad when the wind picked up and quanting was no longer necessary. The sails swelled and the boat glided through the open water, leaving behind the narrow dykes. The sky was clearing and the sun was beginning to shine. It was truly beautiful.

There was still a lot to do, as boats rarely travel in a straight line. They mainly move diagonally. The skipper explained the theory of sailing always in relation to the wind. I must admit most of it went over my head, but gradually I understood when we were "tacking" or "jibing". In both cases, I knew I had to duck quickly when the skipper called, to avoid getting hit by the boom, which in our boat was a very heavy piece of wood. Our boats (there were five in the flotilla), were 28-foot 1930s gaffrigged mahogany, all made of wood, metal and canvas with no motor. For their propulsion, they depend on a main sail and a "jib" sail. It takes great skill to handle these to get the most out of the conditions of the wind. The main sail is handled with the "main sheet" which at times requires 
considerable strength to pull, depending on the strength of the wind. I was not experienced enough to handle the main sheet, but I often trimmed the jib sheet, under the instruction of the skipper. It surprised me very much that boats could sail against the wind, as well as with the wind behind. I cannot claim to have understood how this is done, but I knew that the aim was mainly to keep the sails as full as possible. I learned many more things. For example, that the wind can suddenly change direction, and trees affect the wind dramatically, sheltering the sails when trying to manoeuvre in the dykes, and, therefore, slowing the boat substantially.

One of the most complex tasks, which required team work, was going under bridges, because the very tall mast must be brought down and quanting is needed to keep the boat moving. Once we got through a bridge, we had to moor again and raise the mast. Lowering the mast must often be done quickly and involves many small tasks. We soon learned to adopt certain strategic positions and carry out the tasks efficiently and smoothly, removing and replacing pins, pulling the lines or letting them go at the right times, and securing the lines with knots I had never done before. I often asked someone to check my knots. I liked the feeling of making my contribution to these tasks, getting the job done; but also, I felt safe sharing the responsibility, rather than doing things on my own. I would have felt awful if something had gone wrong due to something I had done.

At the end of each day, we took turns to cook. Cooking was a pleasant chore because it was a way to reward ourselves for the hard work. It was relaxing too, a familiar task that stood in contrast to all the new and challenging jobs of the day. After dinner, there were often long conversations full of sailing stories, containing names of places I have never been to and of different types of boats I knew nothing about. For someone like me, who did not belong to the world of sailing, the stories didn't make a lot of sense. I was always tired and ready to sleep. Fortunately, my past experiences of camping meant that sleeping in the very confined space of the cabin was not a problem, but I learned that others found it difficult.

Overall, the plans for the week were unknown to me. Decisions as to where we would go each day were made by others. I felt I did not need to know. I trusted that we would go to the best places and our itinerary would be a sensible one. I realised these decisions very much depended on the weather. So, not only I was not in control but the skippers, although to a lesser extent, also depended on conditions that fluctuated. I was told this is very much in the nature of sailing. This applies even more strongly to the actual handling of the boat. The skipper tended to explain a lot, which was very useful for me, but sometimes would ask to take the main sheet and handle the tiller with the other hand. He said that sometimes it was difficult to put things into words, and that it was simpler if he could sail the boat himself, especially in difficult situations. That way he could feel what was best, how much to bring the main sheet in or loosen it, and the subtle changes in direction required to get the most out of the wind.

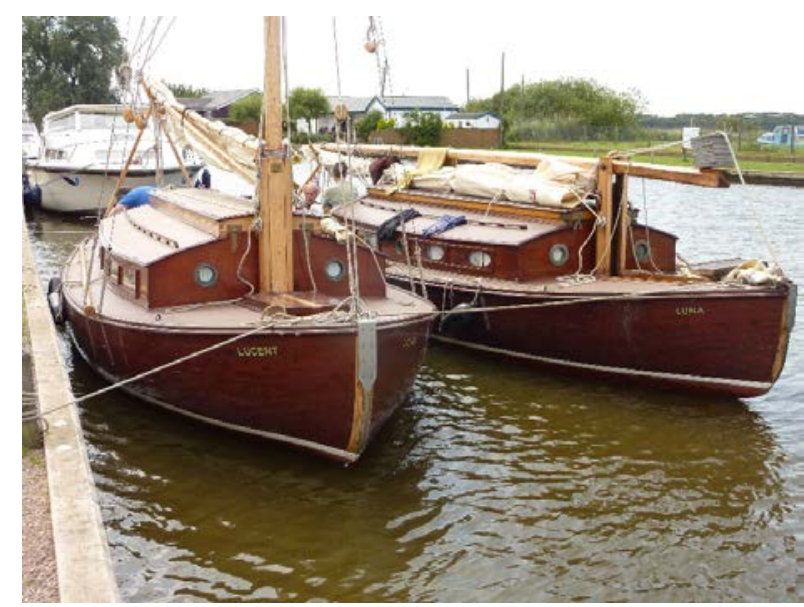

The skipper was a very interesting character. He had vast experience of sailing, but at some point I learned he had only sailed this type of boat a few times before. However, it was clear that he developed a strong relationship with it. In the most "hairy" parts, he talked to her: "Come on Lucent", "Do it for me", "That's it, good girl". A man in his mid-sixties, he took his responsibilities seriously, enforcing basic health and safety rules (life jackets were to be worn at all times). In fact, of the five boats in our flotilla, we were the only one to practice "man 
overboard" (with plastic buoys and fenders), which we all enjoyed thoroughly. In the end, I didn't fall in, in the whole week of sailing, nor did anyone in our boat.

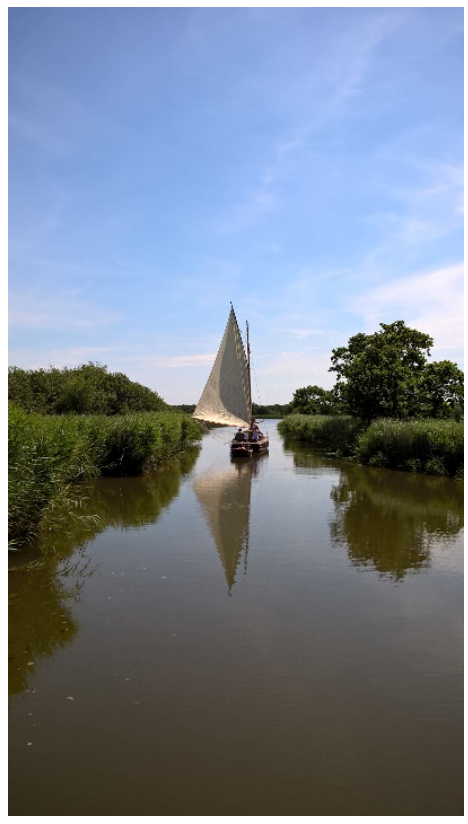

Despite our skipper's vast experience, sometimes things did not turn out as he wanted, and we ended up getting stuck with the bow in the reeds and the wind pushing from behind. It took a lot of skill and effort to get us back sailing in the narrow dykes. Like anyone, he too could lose concentration, for a brief moment, or simply misjudge the speed or direction of the wind when we tacked or jibed. In addition to sailing the boat and making the most of the wind, which at times dropped to almost nothing, attention needed to be paid to other boats, especially motorboats, often handled by inexperienced holidaymakers. However, I never saw him lose his patience in the face of difficulties. But it was the manner in which he related to us that I found remarkable.

As I said before, at an early stage there was a short talk about the theory of sailing in which he explained the basics and introduced us to the names of all the key parts of the boat. After that, he never lectured again. He seemed to have great faith in our ability; the truth is that I was the only true novice as the other two members of our crew had considerable experience of sailing. He always encouraged us to ask questions whenever we weren't sure of something. So, I asked a lot of questions and often checked I had understood his instructions correctly. In situations where conditions can change very quickly you do not want to make mistakes. At times, the skipper's instructions were sharp and actions needed to be carried out without delay. We soon learned to detect the changes in the way he expressed himself and when his tone had an element of urgency.

Did I make mistakes or fail to carry out his commands? Yes, of course. Did these faults have consequences? Yes, but fortunately not serious. Was I the only one to make mistakes? No, everybody made a mistake every now and then. The skipper was always quick to impart new instructions to correct the problem without ever reproaching the person that had made the mistake. When I made a mistake, or did not carry out an instruction quickly (once or twice I got distracted by the beauty of the scenery), I felt slightly embarrassed but never ashamed or humiliated because he always took responsibility for the mistakes: "Forgive me, it was my fault for not explaining things well enough". I think his motto was "It is always the skipper's fault". Maybe his earlier career as a teacher had something to do with it, or his commitment to Buddhism may explain this way of responding to the mistakes of others.

\section{Reflection 1}

So, what have I learned from this experience of sailing? Before I tackle this question, I would like to reflect briefly on the experience of first-person writing and how it came about.

Like all university lecturers, I reflect on my experiences of teaching and working with students. These can be early experiences or my memories of them, especially of the first years, as a demonstrator and later as a teaching assistant, then my first proper lecturing job, and later starting to teach in the UK in the mid-nineties, under very different rules (which felt very formal and bureaucratic). A quarter of a century of teaching is a lot of experiences. I have done reflective writing using blogs and ePorfolios, but had not written in this style about non-work-related experiences for a very long time. 


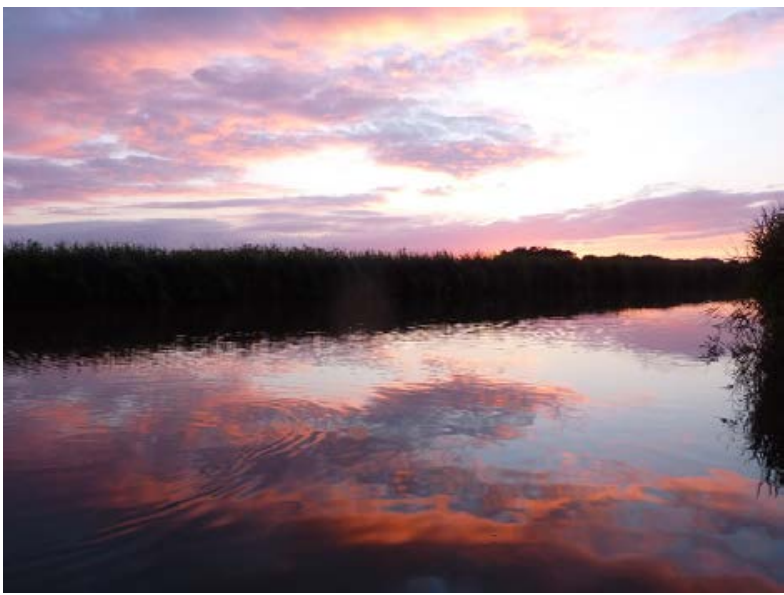

My inspiration came after listening to Kimberley Dark at the Bedfordshire Systemic Practice Spring School that took place in the Lake District earlier this year (26-28 April). Perhaps the connection between Lake Windermere and the Norfolk Broads (the water, stunning views, etc.) has played an important part in fuelling my urge to write as a means of learning from my experience.

The fact is, towards the end of the sailing week I had the realisation that the most useful learning was not about sailing, but related to what happens in a different part of my life: teaching and, more specifically, supervision of students in the Professional Doctorate in Systemic Practice (at UoB). I think the peculiarity of my experience of being in the position of a novice played a key role in this learning. I say peculiarity because it is not something I am used to. My job, certainly, entails learning, all of the time, but I am an advanced learner. I am supposed to have expertise and use it to support other people's learning. However, my experience of sailing in the Norfolk Broads for a week and writing about it has made me more deeply aware of what students might experience and what a supervisor's role could be about.

Like me with regard to sailing, students may initially feel utterly incompetent and insecure, in terms of the much-talked-about notion of "doctorateness", despite being competent professionals in their own fields. So, I wanted to explore my own experience more deeply in order to gain understanding of what theirs may be like and, maybe, discover ways to support them better. What happened in the Norfolk Broads was about living moment-by-moment "re-orienting [myself], directly and materially to [my] surroundings" and what writing about it allows me to do is to "bring attention to [my] living, spontaneously responsive, expressive, bodily movements, and to shift attention away from our current, radical intellectualist and in fact, mechanistic concerns" (Shotter 2013, p.134). Noticeably, I did not attempt to apply some theoretical understanding either in Norfolk or when I did my firstperson writing and I think that brings about important benefits.

I will make links to theoretical knowledge in the next section. In many ways, this article shares aspects of auto-ethnography, sociopoetics and reflexive ethnography, which are all ways of using first-person styles of writing for the purpose of understanding some portion of social life (Ellis \& Bochner 1996), but it does not constitute a piece of research designed a priori and carried out according to a plan.

\section{Reflection 2}

In this section, I have attempted to discuss more explicitly some aspects of my personal experience of learning to sail as they relate to important aspects of the everyday experiences of students and supervisors in the professional doctorate in systemic practice. By doing that, I hope to draw the reader's attention to these aspects and provoke further thought.

As with any metaphor, there are aspects in the first domain (sailing) that do not relate to any aspects of the second domain (learning and teaching in the doctoral programme on systemic practice) and, therefore, they do not contribute any important understanding. It is always possible, though, that readers can see their relevance where I have not. 


\section{Theme 1: Fear and how this is overcome}

During the sailing holiday, I experienced fear of falling in the water but also of failure (we know how important achievement and success are in our culture). I also feared embarrassment. In the case of someone's doctoral studies, it may be fear of appearing ignorant, not knowing enough about epistemology or social constructionism, not having read the authors that the supervisors mention, or fear of not writing well in the reflective, dialogical or conceptual style expected. In a nutshell, fear of not being good enough for a doctorate. As Carl Rogers (1951) explained, significant learning directly relates to the Self, because it involves radical challenges to the ways we see the world and ourselves. Knowles (1990), referring more directly to adult education, stated that "significant learning is often threatening to an individual" and emphasised the need to "provide an acceptant and supportive climate", but immediately added "with heavy reliance on student responsibility" (p.49). It is Maslow's (1968/1972) discussion of "Growth and safety" that I find most interesting: This author pointed out that a child (but also an adult) "reaches out to the environment in wonder and interest" if she is "not crippled by fear (...) and feels safe enough to dare" (p.50-51). For Maslow, growth is chosen by the safety-need gratified individual when "the delights of growth and anxieties of safety are greater that the anxieties of growth and the delights of safety" (p.45).

In my case of sailing, I learned how to perform new tasks, like quanting, through perseverance, by taking small steps, one step at a time. And, then, there would be a breakthrough: I got the hang of it and it began to get easier. In academic work, reading a difficult article also involves a struggle. We often experience a strong feeling of "not getting it", even after reading a sentence several times. Like quanting, we must keep reading, stumbling over the terms, making notes and trying to interpret what the author meant and how it relates to my work. We might need to read more, go back to some of the author's original sources, or even read earlier work by the author. Maslow described this gradual process in somewhat similar terms: "[G]rowth forward customarily takes place in little steps, and each step forward is made possible by the feeling of being safe, of operating out into the unknown from a safe home port, of daring because retreat is possible" (p.45). Unlike quanting, however, one's actions do not usually have an immediate tangible effect and, most of the time, all we may get are glimpses of understanding, like momentary flashes of light. We often have to wait some time to get confirmation that we have understood. Finally, succeeding at a task and improving results in "feedback for the Self, in the feeling of certainty ("This I like; that I don't for sure"); of capability, mastery, self-trust, self-esteem" (p.50). It was certainly very important for me to savour the sweet taste of success (at the small tasks) and overcome my fear. I believe it is the same for the doctoral student.

\section{Theme 2: The need for support}

Rogers, Maslow and Knowles have all highlighted the need for support, but what shape should this take? My first realisation is that tasks that seem simple (or just non-issues) to a supervisor might sometimes seem very difficult to a student. However, because doctoral students are also professionals, they may be unable or unwilling to admit that they are afraid or seek help. Therefore, the first form of support entails the need to look out for signs of fear or confusion, and resist the temptation to dismiss them ("But what's the big deal?"); also, to be careful and not rush to help, causing embarrassment. Like the skipper, I can make it easy for the student to ask questions at any point. I must also trust the student with small tasks and allow them to learn from their mistakes. I also need to recognise the small break-throughs as well as the big achievements, and give praise when it is due. Although, as Maslow (1968/1972) says "for the adult, others can be and should be less important than for the child" (p.50), I think adults too can be vulnerable and deeply hurt by ridicule from peers or a dismissive supervisor. 


\section{Theme 3: A skilful and gentle guide}

Although support is a vital part of the role of the supervisor, there is much more to it. A supervisor is an experienced learner who is passionate about his/her subject area (aren't we all?). This means we are also prepared to learn with our students (jointly). The guidance I provide will include conceptual explanations, as well as stories of how I have done things in the past. Sometimes, though, like the skipper, I will perhaps run out of words and prefer to show a student how something is done ("Let me try this out"). I might not always get it right. Other times, I may not have any advice to offer and should be honest enough to say so. The student will then have to work it out by him/herself or consult another expert. Once again, it is all about timing, responding to what is required in different circumstances. This is a key idea I will return to in the next theme. Sufficient trust between student and supervisor will be needed for all these pedagogical approaches to have a space. This is an essential part of the relationship that exists between supervisors and students as the context where a skilful pedagogy occurs.

Although the student-supervisor relationship is a broad topic that exceeds the aims of this article, I would nevertheless like to highlight a very important skill I saw the skipper display on many occasions. This refers to his ability to avoid embarrassing the learner. I realised how crucial this is. For me, this applies mostly to my feedback which should be guided by a fundamental respect for the fear of a learner. It seems appropriate to return to Maslow (1968/1972) at this point: "Only one who respects fear and defence, can teach". The good educator "practices as if he understood that gentleness, sweetness, respect for fear, understanding of the naturalness of defensive and regressive forces, are necessary, if growth is not to look like an overwhelming danger instead of a delightful prospect" (p.48).

\section{Theme 4: Theory and conceptual explanations}

The absence of a conceptual framework on which to hang the myriad new concepts that rained on me at the start of my sailing week may be something that doctoral students recognise. Although there are course handbooks and tutors advise on readings, theories often aren't what they need. John Shotter (2013) referred to theoretical knowledge as "knowledge after the facts" and pointed to the inadequacy of such knowledge as a starting point to our scientific inquiries (Shotter 2014). Instead, we could argue that we learn by participating and responding to the most obvious and urgent aspects of a situation. It surprises me how much I was a part of a larger flow of events (the wind, the boat, the crew's actions, etc.), a world in motion that I certainly had little control over, far less understood conceptually, and how I was trying to "fit [my] efforts (...) into the 'requirements' of [my] surroundings, to move this way and that in accordance to the changed circumstances [I myself] produced as a result of each step [I] took" (Shotter 2013, p.138). I was, in all honesty, "trying to get things right" (p.140) in terms of the specific situation (the boat stationary due to the lack of wind, the actions of the others, the goal stated by the skipper, etc.). None of this appeared in the manual and, certainly, it was not the result of our attempt to implement any sort of plan. On the contrary, this was truly a "dialogical reality" (Shotter 2013). For our students too, the real learning happens by doing and the concepts make sense only in that context. I am advocating a strongly reflexive approach that starts with experience (of one's practice as a lecturer or a family therapist) and expresses (and explores) it through writing, in order to learn from it.

Many others have proposed privileging experience in different ways: action research (Coghlan \& Brannick 2005; Kemmis 2003; Lewin 1946; Reason \& Bradbury 2008) experiential learning (Beaudin 1995; Gibbs 1988; Gregory 2006; Kolb 1984; Moon 2004; Mulligan \& Griffin 1992; Tosey 2006), ethnographic alternatives (Ellis \& Bochner 1980), reflexive practice research (Simon 2014) are a few examples. So, what role do concepts and frameworks have in such inquiries? I side with Shotter, in that they are useful "objects of comparison" (Shotter 2013) that allow certain aspects of experience 
to stand out (heuristic devices) and also become useful literary tools ("props") that aid our job as we write and explore our experiences.

\section{Theme 5: Teamwork}

In my experience of sailing, a lot of the time there was a clear division of labour. But a plan, if it can be called so, was devised on the hoof, just a few minutes in advance ("We will moor on the starboard side and when we approach, Tom will take the bow line and Alfredo the stern line..."), with the skipper's judgements being shaped by the positions of each crew member at a particular time, as well as his or her ability, and other practical considerations. So, does this mean that every task was approached as a whole new task? Yes and no. Every situation was indeed a new combination of factors, but at the same time, similarities were noticed and we tended to repeat things that had worked before. Others played a key role in such dynamics, but their support was available rather than offered: having someone to ask questions of, or check with that things were on the right track, or having someone at hand to help if help was needed. This related directly to the notion of safety mentioned before. I often experienced the feeling of being useful.

As we all know, throughout the duration of a student's studies, there are numerous conversations; some formal (meetings) and others informal (emails), some are face-to-face while others occur on Skype. Drafts are commented upon and revised many times, based on feedback. It is often the case, that, after a while, it is no longer possible to determine with absolute certainty the authorship of ideas. Although we would like to think they are mostly the student's, we know supervisors, authors, participants, peers, and many others, have helped shape those ideas in a truly "dialogical space". The knowledge constructed is neither the student's nor the supervisor's because it is the result of "joint action" (Shotter 1993) or, as the author more recently described it, "third agency" (Shotter 2013).

\section{Theme 6: Unfamiliar worlds}

Throughout my sailing week, I encountered a universe of terms that referred to spaces, objects and places whose meanings appeared capricious, mysterious, foreign. The boat itself was a space that felt unfamiliar and, quite literally, unstable under my feet. It was full of objects whose use was not entirely clear at first, but that I later used repeatedly and related to in a very sensory way (e.g. a "sheet" that I pulled to help "hoist" a sail or "sweated" before someone else secured it to a "cleat"). Learning a completely new set of skills poses many unique challenges. This experience must resemble that of a student, reading the first piece by Kenneth Gergen or John Shotter. However, as with the objects on a boat, the concepts and ideas a learner encounters can end up becoming invaluable tools and shaping his thinking in powerful ways.

During their studies, students will attend many gatherings, listen to many presentations, hear the supervisors ask insightful questions, and wonder if they will ever be in such a learned position. At conferences and academic events, they will sometimes hear academics tell stories about places they have never seen or events that took place well before their time. But, as we know, it is only a matter of time before they too will be giving presentations and eventually be admitted to the inner circle. They will then have stories to tell and will be able to take part in interesting, unrepeatable and sometimes unforgettable conversations, which will become themselves embedded in wider ongoing conversations.

\section{Theme 7: New demands on the body (and the mind)}

Learning new skills makes new demands on the body - in my case, of learning to sail, lifting the heavy 15 -foot quant, moving quickly from one side of the boat to the other, ducking to avoid the 
boom that could deliver a potentially lethal blow to my head, and most of all, keeping my balance precariously on a deck as I pushed with the quant. As a consequence, my body changed: not only did my skin darken through the week and I collected a few bruises and a twisted ankle, but I observed that, after a few days, my balance changed. I didn't just feel more stable standing on the boat, but when on land, I felt the ground move under my feet and a gentle swaying, as if I were still on water! This feeling lasted a few more days into the following week.

Embarking on a doctoral degree also requires changes in one's bodily and mental habits. Finding time to read and write on a regular basis may mean changing sleeping patterns or reorganising one's schedule. At times, we will feel excited or worried and ideas can keep turning in our minds preventing us from falling asleep. Stress or exhaustion are things to look out for and "listening to one's body" is useful. A regular practice of Tai Chi/Chi Kung (or any mindful physical exercise) can take us away from the typical academic (unhealthy) habits and help us reconnect with our bodies. Doctoral work might mean coming into contact with a range of new IT resources (e.g. mind-mapping software, referencing tools, blogs, etc.) and unfamiliar methods. Like craftsmen and women who work with a tool long enough, academics develop expertise in the use of resources and tools, mastery that allows us to use them as "prosthetic devices" (Shotter 1993) to feel our way through a subject. Doctoral students can also develop their own ways of approaching experience. There will be originality in every doctorate.

\section{Theme 8: Being immersed in a tradition, a group with a culture}

Meaning comes from a "shared background" and a "knowing from within" that derives from belonging to a group or a culture (Shotter 2013). Perhaps, it is fair to say that a strong belonging to a community and a culture where sailing is traditional (perhaps a fishing community) applies to very few people in today's world. For some people, sailing is more of a sport or hobby they learned when they were young. And for others, like me, it is something you could take up later in life. I think that, for the majority, it is more like learning to speak a second language or being an immigrant. A journey that takes us from feeling like an outsider to becoming an insider.

At the end my week of sailing, people told me I could consider myself a sailor. Although I didn't want to admit it, I had been accepted into this group. I couldn't say "I have not sailed before" anymore, because I had. I could name and define what many parts of the boats are for. I could explain, in very basic terms, how they sailed. I knew many of the routines that needed to be performed at different times, although I would never claim to know how to sail one of these beautiful boats myself. Most importantly, I had made some friends.

As a new supervisor in the Systemic Practice Doctoral Programme, my experience of attending the Spring School earlier in the year was a somewhat similar experience, part of the process of moving from the outside to the inside. For the students, joint attendance at different gatherings may provide a sense of belonging to a cohort and the programme. Supervisors and more advanced students serve as role models providing an idea of what they themselves can aspire to become. The processes of learning occurring in parallel to the construction of identity have been described as "peripheral legitimate participation" (Lave \& Wenger 1991) and as occurring in "communities of practice" (Wenger 1999). 


\section{Theme 9: Control (or lack of it)}

Sailing is an activity in which everyone accepts the importance of the weather and, especially, of the wind. At a basic level, without any wind there can be no sailing, and with very strong winds sailing becomes impractical, even dangerous. But what the expression "ideal conditions for sailing" means depends on each sailor and his or her perceived ability. There is also another notion which everyone who sails recognises: conditions are always changing. In this context, planning becomes more fluid. A general plan to go to $x$ or $y$ place, may have to be revised at the last minute. This requires a pragmatic approach with a great degree of flexibility. The weather and other factors associated with the water (currents, tides, etc.), are always shifting. This experience of the world relates to some of Shotter's descriptions of a social world where structures are only there for a moment, hence the term "dynamic stabilities" (Shotter 1993).

In the world of academia, the frameworks, timetables and plans, set up by others and sometimes by ourselves, are important, but they do not determine the course of events; in academic work, like any area of life, we must interact with others and our intentions do not determine the outcomes, the process does. This is the nature of "joint action". Perhaps, what is needed is a special sensibility to notice and respond appropriately to our circumstances, in tune with "the agentive nature of our current surroundings "calling" actions out from us that we would otherwise (...) not perform" (Shotter 2013, p.150). "Right action" (i.e. appropriate action at a given moment) (Nhat Hanh 1999), to use the Buddhist notion, arises out of a mindful way of being (deeply present in the moment and in tune with one's surroundings), rather than an analytical/theoretical detached approach.

\section{Concluding remarks}

In this article, I have attempted to explore a recent personal experience of being in a position of a complete novice. As an experienced academic, this is an uncommon position to be in, and this fact gave me a precious opportunity to gain insight into the experiences of students in a doctorate programme, who might feel incompetent and insecure despite being competent professionals.

I deliberately chose to start with experience, my own personal experience, not from conceptualisation, and I used my experience of sailing as a metaphor for what happens to students and supervisors. I made a selective use of concepts from very few authors as "objects of comparison" (Shotter 2013) to make some aspects of the similarities between the two domains of the metaphor more apparent, and to help me express their significance more eloquently, also because I am part of a "tradition of argumentation" (the discipline of social psychology and a social constructionist perspective) that serves as a background and a home for my thinking.

I have not attempted to carry out any kind of systematic literature review or draw on a body of knowledge. I have not even cited a "representative" sample of the authors' work I cited. I know of many more sources I could have cited, but then the emphasis would have shifted away from experience, and more towards generalisations about objective facts, which would have been of little use (Shotter 2012).

My intention has been to remain close to both the experience of a beginner/novice sailor and the experience of trying to learn academically within the very specific context of a professional doctorate in systemic practice. I hope, from reading about their similarities, that the reader can foresee new possibilities for going about the business of learning as a supervisor or as a student. 


\section{Acknowledgements}

Many thanks to James Kirwan for allowing me to use three of his photographs to illustrate the article, Jim Grant for his expert advice on sailing, and Lucy Thomas for her invaluable help with proofreading and editing. Of course, my gratitude goes to the members of my crew and all those who made a wonderful experience in the Norfolk Broads possible.

\section{References}

Beaudin, Bart (1995). Experiential learning: Theoretical underpinnings. Fort Collins, U.S.A.: High Plains Intermountain Centre for Agricultural Health and Safety.

Coughlan, David \& Brannick, Teresa (2005). Understanding action research. Doing action research in your own organisation. London: Sage.

Ellis, Carolyn \& Bochner, Arthur P. (Eds.) (1996). Composing ethnography: Alternative forms of qualitative writing. Walnut Creek, CA: Altamira Press.

Gibbs, Graham (1988). Learning by doing [Online]. Geography Discipline Network. Available: http://www2.glos.ac.uk/gdn/gibbs/index.htm [Accessed 19.9.06].

Gregory, Josie (2006). Principles of experiential learning. In: Jarvis, Peter (Ed.) The theory and practice of teaching. London: Routledge.

Kemmis, Stephen (2003). Action research. In: Hammersley, Martyn (Ed.) Educational research: current issues. London: Paul Chapman \& Open University.

Knowles, Malcolm. S. (1990). The adult learner: a neglected species. Houston: Gulf Publishing Company.

Kolb, David. A. (1984). Experiential learning: Experience as the source of learning and development. Englewood Cliffs, NJ: Prentice Hall.

Lave, Jean. \& Wenger, Etienne (1991). Situated learning: legitimate peripheral participation. New York, NY: Cambridge University Press.

Lewin, Kurt (1946). Action research and minority problems. Journal of Social Issues, 2, 34-46.

Maslow, Abraham. H. (1972). Defence and growth. In Silberman, Melvin. L., Allender, Jerome. S. \& Yanoff, Jay M. (Eds.). The psychology of open teaching and learning: An inquiry approach. Boston: Little, Brown \& Co. (original work published 1968).

Nhat Hanh, Thich (1999). The heart of Buddha's teaching: Transforming suffering into peace, joy and liberation. London: Rider.

Moon, Jennifer (2004). Handbook of experiential and reflective learning: Theory and Practice. London: Routledge Falmer.

Mulligan, John. \& Griffin, Collin (Eds.) (1992). Empowerment through experiential learning: explorations of good practice. London: Kogan Page.

Reason, Peter \& Bradbury, Hilary (Eds.) (2008). The Sage handbook of action research. London: Sage.

Rogers, Carl. R. (1951). Client centred therapy. London: Constable.

Shotter, John (1993). The cultural politics of everyday life: Social constructionism, rhetoric and knowing of the third kind. Buckingham: Open University Press.

Shotter, John (2013). Agentive spaces, the 'background', and other not well articulated influences in shaping our lives. Journal for the Theory of Social Behaviour, 43, pp.33-154. 
Shotter, John (2014). Methods of practitioner in inquiring into 'the stuff' of everyday life and its continuous coemergent development. In: Gail, Simon \& Chard, Alex (Eds.) Systemic inquiry: Innovation in reflective practice research. Farnhill: Everything is Connected Press.

Simon, Gail \& Chard, Alex (Eds.) (2014). Systemic Inquiry: Innovations in reflexive practice research. Farnhill: Everything is Connected Press.

Tosey, Paul (2006). Experiential methods of teaching and learning. In Jarvis, Peter (Ed.) The theory and practice of teaching (2nd edit). London: Routledge.

Wenger, Etienne (1999). Communities of practice: learning, meaning, and identity. Cambridge: Cambridge University Press.

\section{Author}

Alfredo Gaitán, PhD, is a Senior Lecturer in social psychology. He has a strong interest in teaching and learning, specifically learner development and construction of knowledge. Alfredo has also supported the use of ePortfolios and patchwork text assessments. He is a supervisor in the Professional Doctorate in Systemic Practice at the University of Bedfordshire.

Alfredo Gaitan, School of Psychology, University of Bedfordshire, Park Square, Luton LU1 3HU.

Email: alfredo.gaitan@beds.ac.uk

URL: http://www.beds.ac.uk/howtoapply/departments/psychology/staff/alfredo-gaitan

\section{Citation}

Gaitàn, Alfredo (2017). The peculiar experience of being a complete novice: A reflection on supervising systemic practitioner researchers on a doctoral programme. Murmurations: Journal of Transformative Systemic Practice, 1 (1), 45-56. https://doi.org/10.28963/1.1.5 